\title{
A laboratory simulation of the carbonization of sunflower achenes and seeds
}

\author{
F. Braadbaart ${ }^{\mathrm{a}, \mathrm{b}, *}$, P.J. Wright ${ }^{\mathrm{c}}$, J. van der Horst $^{\mathrm{a}}$, J.J. Boon ${ }^{\mathrm{a}}$ \\ ${ }^{\text {a }}$ FOM Institute for Atomic and Molecular Physics, Kruislaan 407, 1098 SJ Amsterdam, The Netherlands \\ ${ }^{\mathrm{b}}$ Department of Earth Sciences-Geochemistry, Faculty of Geosciences, Utrecht University, P.O. Box 80021, 3058 TA Utrecht, The Netherlands \\ ${ }^{\mathrm{c}}$ Department of Anthropology, University of Missouri-St. Louis, St. Louis, MO 63121, USA
}

Received 20 January 2006; accepted 4 July 2006

Available online 2 October 2006

\begin{abstract}
The current project describes physical and chemical alterations that result from the thermal exposure of sunflower achenes and seeds. Specifically, achenes and seeds were heated at temperatures ranging from 130 to $600{ }^{\circ} \mathrm{C}$ under anoxic conditions for 60 min. Changes were measured in mass, relative percentages of $\mathrm{C}$ and $\mathrm{N}$, internal and external morphology, molecular composition by direct temperature-resolved mass spectrometry (DTMS) under EI conditions, and the reflectance on polished specimens. The main constituents of sunflower seeds are lipids and protein, while the pericarps or hulls enclosing the seeds have a ligno-cellulosic structure. The morphology of achenes and seeds remains intact following exposure which makes the identification of the residues possible. The results of the sunflower experiments were compared to previous experiments conducted with peas and wheat grains. Up to approximately $340{ }^{\circ} \mathrm{C}$, the molecular conversion of polysaccharide and protein rich peas and wheat grains follow similar pathways, while the lignin present in sunflower achenes follows its own unique pathway, resulting in a different molecular composition. At higher temperatures the molecular composition of the three propagules becomes identical. In addition the reflectance of the three propagules is identical confirming the similarity in molecular composition. Lipids show a different behaviour compared to the other three biopolymers; from $370{ }^{\circ} \mathrm{C}$ no oils are observed in the heated specimens and the DTMS-EI measurements show no lipid markers. Apart from evaporation of the triacylglycerides it is suggested that steroids have a high resistance against thermal degradation and are converted into aromatic moieties.
\end{abstract}

(C) 2006 Elsevier B.V. All rights reserved.

Keywords: Sunflower; Heat treatment; Carbonization; DTMS; Reflectance; Lipids; Lignin; Archaeobotany

\section{Introduction}

Botanical remains are an important part of the material remains of the archaeological record and reflect human uses of plants for food, medicine, rituals, tools, and construction among other behaviours [1]. Most botanical remains are derived from open-air archaeological sites in mesic contexts. There, they are subjected to oscillations between relatively wet and dry regimens that increase their susceptibility to chemical degradation [2]. The host of small organisms, including fungi and bacteria that are common to mesic environments, negatively impacts the survival of these remains. One way in which botanical remains survive

\footnotetext{
* Corresponding author at: FOM Institute for Atomic and Molecular Physics, Kruislaan 407, 1098 SJ Amsterdam, The Netherlands.

E-mail address: brabra@wxs.nl (F. Braadbaart).
}

these natural processes is carbonization, a process equivalent to thermo chemical conversion. Following carbonization, the material can be incorporated into sediments to become part of the archaeological record. However, numerous post-depositional processes subsequently affect their preservation and archaeologists introduce retrieval, analytical and theoretical processes as they collect and analyse the surviving remains [3,4]. These effects will change the character of the carbonized remains and may, for example, mask or exaggerate patterns in plant resource exploitation or even suggest change where none occurred. It is, therefore, of great importance to know how carbonized botanical remains derived from the archaeological record have acquired the physical and chemical characteristics that we observe at their recovery. This study addresses the physical and chemical properties of botanical material that are related to the carbonization process and prior to their deposition, collection and analyses. 
Among the carbonized botanical materials, found in the archaeological record, seeds and fruits are omnipresent [5]. Apparently favourable conditions exist for the carbonization of these propagules. The effects of the post-depositional processes on carbonized propagules are best studied by the establishment of the physical and chemical properties of modern counterparts of the archaeological propagules after carbonization. To obtain further insight into the carbonization process of seeds and fruits, a simulation in the laboratory was carried out by heating modern propagules in a tube oven under anoxic conditions at atmospheric pressure [6-8]. The following species were selected for this study: emmer wheat grains (Triticum dicoccum Schübl), pea seeds (Pisum sativum L.) and sunflower achenes (Helianthus annuus L.). The former propagules are monocotyledons and the latter two are dicotyledons. All three are frequently retrieved from archaeological sites.

The term carbonization is usually used in a general way without an indication of the circumstances under which it took place. In this study we prefer to use the term heat treatment (under anoxic conditions) instead with an indication of the temperature applied and the time of exposure of the samples to the heat source.

Earlier studies have assessed the physical and chemical changes as a result of heating of polysaccharide/protein rich emmer wheat grains and pea seeds [6-8]. Wheat and peas have been important food sources for Europe since their domestication in Southwest Asia (8500 B.C.) [9]. The studies indicate that most of the physical changes are related to the original morphology and anatomy of the wheat grains and the peas. This means that each propagule has its own characteristic changes as a function of the applied temperature and the time of exposure to the heat source. The results show that chemical changes, which are characterized by the transformation of the polysaccharide/protein rich material into a material consisting of aromatic compounds, are identical for both propagules.

The current study describes the changes, as a result of heating, of the physical and the chemical properties of sunflower achenes and seeds. Wild sunflowers were an important food source for PreContact hunters and gatherers of North America. In the United States, domesticated sunflower dates to the second millennium [10,11]. Sunflower achenes are a single seeded fruit, composed of a seed enclosed by a multi-layered pericarp or hull. By removing the pericarp the seed is obtained. Because the main constituents of the achenes are polysaccharides and lignin in the pericarp, and oils as well as proteins in the seed, the current investigation is a necessary addition to previous work involving polysaccharide/ protein rich emmer wheat and peas. Both achenes and seeds were heated at temperatures ranging from 130 to $600{ }^{\circ} \mathrm{C}$ for 60 min under anoxic conditions at atmospheric pressure. Experiments were performed to measure changes, as a function of the temperature, in mass, morphology, bulk chemical composition, molecular composition and reflectance on polished samples. Changes in dimensions will be discussed elsewhere in a subsequent study [23].

\section{Materials and methods}

\subsection{Samples}

The sunflowers were grown by Wright in an experimental garden situated in St. Louis (Missouri, USA). The seeds were obtained from the North Central Regional Plant Introduction Station, part of the United States National Plant Germplasm System. The variety, Arikara, was chosen on the basis of prior carbonization experiments by Heiser [12,13]. The achenes were harvested in the fall of 2004. Because achenes as well as isolated seeds are recovered from archaeological contexts both forms were used for this experiment. The experimental seeds were separated from achenes by manual removal of the pericarp or hull.

The average chemical composition of achenes, pericarp and seeds is shown in Table 1 [14]. These values are strongly affected by the variety of sunflower [17]. Lipids and proteins are the main components of the seed. The pericarp that represents 23-32 wt.\% of the whole achene [15], consists mainly of lignin, pentosans and cellulosic material [18].

\subsection{Heat treatment}

Sunflower achenes and seeds were heated in a pre-heated Carbolite tube oven (model MTF 12/38/250) in which the rate of heating was limited by setting a ramp rate of $2{ }^{\circ} \mathrm{C} \mathrm{min}^{-1}$. The samples were placed in an open Pyrex vessel, which was inserted in a $30 \mathrm{~cm}$ long Pyrex tube $(\varnothing 2.3 \mathrm{~cm})$ at $18 \mathrm{~cm}$ from the inlet. The experiments were conducted under a constant flow $\left(150 \mathrm{ml} \mathrm{min}^{-1}\right)$ of nitrogen at atmospheric pressure. To determine the time of exposure to the heat source, initially, 10 achenes were placed in the Pyrex vessel and heated, at an oven temperature $\left(T_{\text {oven }}\right)$ of $310^{\circ} \mathrm{C}$, for $7.5,15,30,60$ and $120 \mathrm{~min}$

Table 1

Average chemical composition of sunflower achenes, hulls and seeds on dry basis ${ }^{*}$

\begin{tabular}{llll}
\hline & $\begin{array}{l}\text { Achene } \\
(w t . \%)\end{array}$ & $\begin{array}{l}\text { Hull } \\
(w t . \%)\end{array}$ & $\begin{array}{l}\text { Seed } \\
(w t . \%)\end{array}$ \\
\hline $\begin{array}{l}\text { Proteins } \\
\text { Peptides, amino acids and } \\
\quad \text { other non-protein nitrogen }\end{array}$ & - & - & $20.4-40.0$ \\
Polysaccharides & $10.0-27.1$ & - & $1-13$ \\
Klason lignin & $5-7$ & & \\
Lipids & $34-55$ & $31-64$ & $4-6$ \\
Fatty acids & & $3-8$ & - \\
$\quad$ Palmitic (16:0) & - & & $47-65$ \\
$\quad$ Stearic (18:0) & - & - & $5-7$ \\
$\quad$ Arachidic (20:0) & - & - & $2-6$ \\
$\quad$ Oleic (18:1) & - & - & $0.0-0.3$ \\
$\quad$ Linoleic (18:2) & - & - & $15-37$ \\
$\quad$ Linolenic (18:3) & - & - & $51-73$ \\
Tocopherol & - & - & $<0.3$ \\
Chlorogenic acid & $1.1-4.5$ & - & 0.07 \\
Total minerals & $2-4$ & - & $3-4$ \\
\hline
\end{tabular}

After González Pérez and references cited therein [14], Nuria Canibe et al. [15], Narpinder Singh et al. [16]. 
each. On the basis of these initial results, achenes and seeds were heated for $60 \mathrm{~min}$ at each of the following temperatures: 160, 220, 250, 280, 310, 340, 370, 440, 500, and $600{ }^{\circ} \mathrm{C}$. For each experiment 10 achenes and 10 seeds were used The Pyrex vessel including the achenes and seeds was weighed before and after heating, in order to determine the percentage mass loss. Gases and volatiles were vented and not further investigated.

\subsection{Microscopy}

To study the internal morphology whole untreated achenes were sectioned in a $4 \% \mathrm{Ca}$ formol fixative solution using a Leica VT $1000 \mathrm{~S}$ vibratome. For lipid staining, the sections remained in the fixative for 10-30 min and were thoroughly washed with water. Staining was done in Oil Red solution in $60 \%$ propanol for 10-20 min followed by differentiation in 40 or $60 \%$ propanol until a control section (from which the lipid had been removed) showed no colouration. Sections were gradually hydrated in descending propanol-water mixtures, embedded in glycerine gelatine and studied with a Zeiss Axioplan 2 with brightfield or differential interference contrast (DIC). The DIC images were corrected digitally to remove the slight gradient in brightness. The sections were air dried on filter paper, then, glued on aluminium stubs with silver paint and gold-sputtered. They were studied in a JEOL JSM6400 scanning electron microscope at accelerating voltages that range from 1.5 to $5.0 \mathrm{kV}$.

The residues of achenes, heated at 310,370 and $500{ }^{\circ} \mathrm{C}$, were studied using scanning electron microscopy (SEM) and treated in the same manner as described for the section of the untreated achene.

\subsection{Elemental analyses}

Whole untreated achenes and the residues of whole achenes heated at oven temperatures that range from 160 up to $600{ }^{\circ} \mathrm{C}$, for $60 \mathrm{~min}$, were used. For each experiment two achenes were ground and mixed. $\mathrm{C}$ and $\mathrm{N}$ analyses were executed on a NA 1500 series 2 NCS analyser from Fisons Instruments. The temperature in the combustion reactor was maintained at $1020^{\circ} \mathrm{C}$. The combustion products were separated on a Porapak QS column with a length of $2 \mathrm{~m}$. All stated values are based on at least two measurements that were corrected for $\mathrm{H}_{2} \mathrm{O}$ and ash content (dry and ash free, daf). $\mathrm{H}_{2} \mathrm{O}$ and ash content were determined on a thermogravimetric analyser TGA $2950 \mathrm{Hi}-\mathrm{Res}$. The carrier gas was air and the heating rate was set at $25{ }^{\circ} \mathrm{C} \min ^{-1}$, water content was determined at $105{ }^{\circ} \mathrm{C}$ and ash content at $950{ }^{\circ} \mathrm{C}$.

\subsection{Reflectance measurements}

The reflectance of the optically most homogeneous vitrinite, a major constituent of many coals, has become an internationally accepted measure of rank or maturation of coal [19]. It is defined as the percentage of vertically incident monochromatic light reflected from a highly polished surface of a sample calibrated against the light reflected from a standard of known reflectance. Based on this method, residues of whole achenes, heated for $60 \mathrm{~min}$ at oven temperatures that ranged from 270 to $600{ }^{\circ} \mathrm{C}$, were used to measure the reflectance. For each oven temperature two specimens were embedded in resin blocks and polished. Maximum reflectance measurements $\left(\% R_{\max }\right)$ were performed under oil immersion at a wavelength of $546 \mathrm{~nm}$ using a Leitz MPV II microscope system. Thirty reflectance measurements were made on each specimen and at least two residues heated at the same temperature were used to calculate the mean reflectance. Preparation of polished blocks and reflectance measurements were carried out according to standard methods defined in ISO 7404, part 2 [20] and ISO 7404, part 5 [21].

\subsection{Direct temperature-resolved mass spectrometry (DTMS)}

A JEOL SX-102A double focusing mass spectrometer (B/ E), using a direct insertion probe equipped with a $\mathrm{Pt} / \mathrm{Rh}(9 / 1)$ filament for analysis under electron ionization (EI) conditions, was employed. The sample that consisted of the powdered mixture of two whole achenes and seeds or residues was deposited on the filament and inserted directly into the ion source of the mass spectrometer. Previous measurements on residues of peas showed that the sampling and experimental variance was very small [7]. Therefore, only single measurements were performed. Under EI conditions ions were generated by low voltage electron ionization $(16 \mathrm{eV})$ in an ionization chamber kept at $180{ }^{\circ} \mathrm{C}$ and accelerated to $10 \mathrm{kV}$. The scan range was $m / z, 20-1000$ with $1 \mathrm{~s}$ cycle time and mass resolution of 1000 and 3000 for achenes and seeds, respectively. Data were acquired using a JEOL MP-7000 data system.

\section{Results}

\subsection{Heat treatment at a constant temperature versus time}

The mass loss of sunflower achenes was determined, as a function of time in minutes, at $T_{\text {oven }}=310$ and $500{ }^{\circ} \mathrm{C}$ (Fig. 1). The experimental conditions did not allow continuous measurement of the mass loss during the entire time interval of $120 \mathrm{~min}$. A separate experiment was necessary for each time interval. The results show that the mass loss reaches a level of $40 \%$ after $30 \mathrm{~min}$ of heating at $T_{\text {oven }}=310{ }^{\circ} \mathrm{C}$ and of $80 \%$ at $500{ }^{\circ} \mathrm{C}$ (Fig. 1). Longer exposure to the heat source shows that the mass loss continues to increase, but at a much slower rate. This pattern of mass loss was also observed in previous experiments on pea seeds and wheat grains $[6,8]$. The results of these experiments demonstrate that the higher the $T_{\text {oven }}$ the shorter the time it takes to reach almost constant levels of mass loss. For example it takes approximately $30 \mathrm{~min}$ at $T_{\text {oven }}=340{ }^{\circ} \mathrm{C}$ and less than $10 \mathrm{~min}$ at $T_{\text {oven }}=$ $600{ }^{\circ} \mathrm{C}$. However, a constant level of mass loss is never reached. Based on these results a heating time of $60 \mathrm{~min}$ for sunflower achenes and seeds for each heating experiment is considered sufficient. 


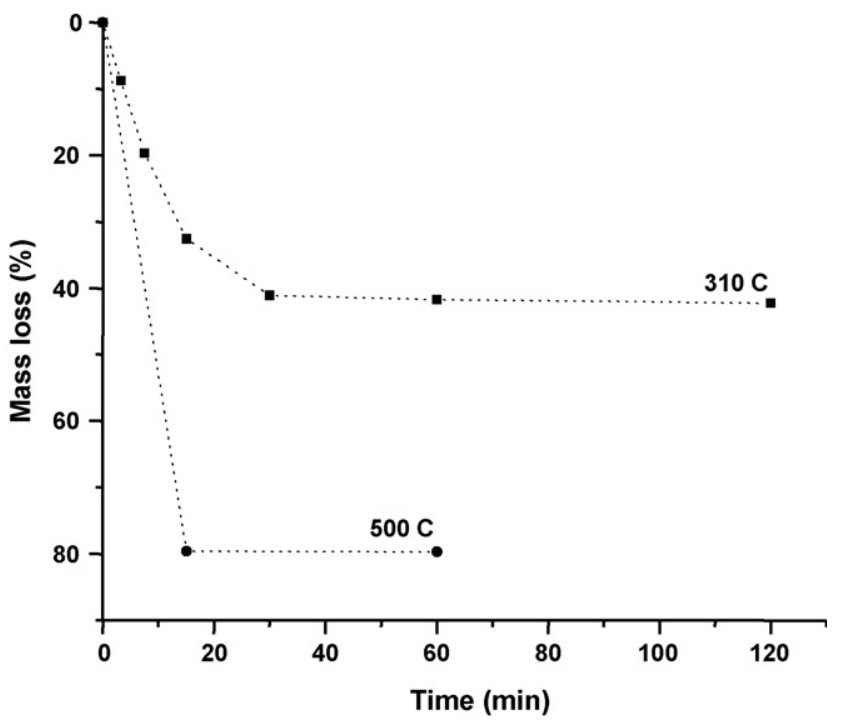

Fig. 1. Mass loss (\%) of heated sunflower achenes (var. Arikara) as a function of the heating time in minutes. The oven temperature is indicated in the figure in ${ }^{\circ} \mathrm{C}$.

\subsection{Heat treatment for 60 min at constant temperatures}

Heating experiments with sunflower achenes and seeds were carried out at oven temperatures in the range of $160-600{ }^{\circ} \mathrm{C}$ for periods of $60 \mathrm{~min}$ (Fig. 2). For each $T_{\text {oven }}$ a separate experiment was carried out. A strong mass loss was observed for both achenes as well as seeds in the range of $T_{\text {oven }}=280-370{ }^{\circ} \mathrm{C}$, after which the mass loss slowly decreases with temperature but does not seem to become constant. For comparative purposes the mass loss of pea seeds, a propagule that does not contain oil, is also shown (Fig. 2) [6]. Pea seeds were heated for periods of 60 min under identical conditions. It shows that the peas have a

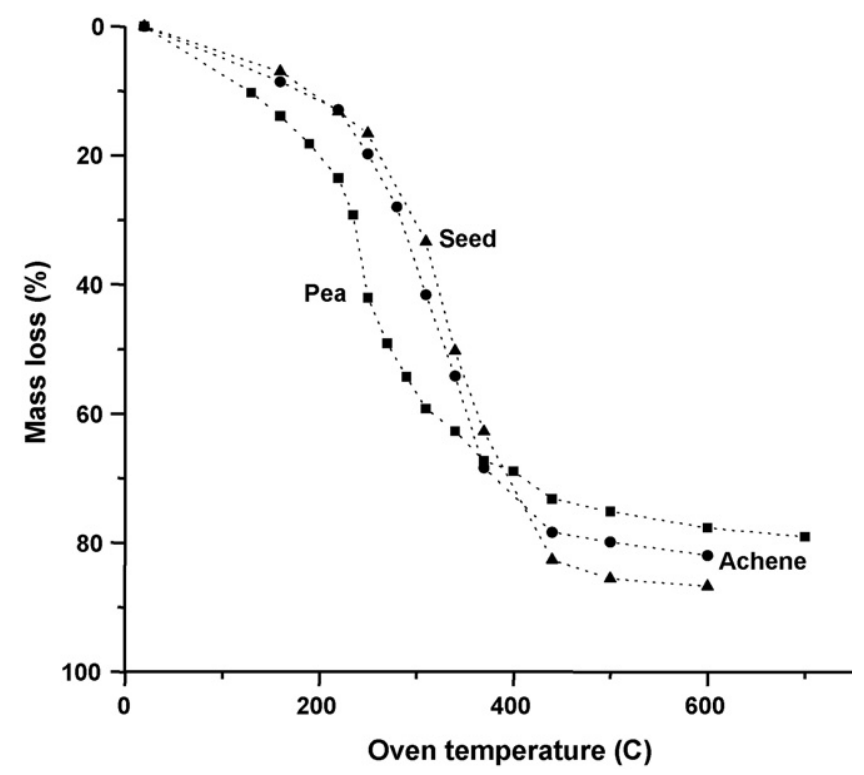

Fig. 2. Mass loss (\%) of sunflower achenes and seeds (var. Arikara) heated for $60 \mathrm{~min}$ as a function of the oven temperature in ${ }^{\circ} \mathrm{C}$. Peas heated for $60 \mathrm{~min}$ after Braadbaart et al. [6]. larger mass loss at temperatures below $T_{\text {oven }}=370{ }^{\circ} \mathrm{C}$, but at higher temperatures the mass loss of the sunflower residues is higher.

\subsection{Morphology and anatomy}

The achene of the sunflower is a dry, simple, one-seeded fruit with the seed attached to the inner wall of the pericarp or hull at only one point. The length of the achenes of the investigated variety varies from 9.5 to $14.1 \mathrm{~mm}$ and the width from 4.4 to $9.4 \mathrm{~mm}$. The achene is pointed at the base and rounded at the top. In cross-section it is roughly four-sided. The achene is variously coloured, ranging from black to white and often in longitudinal stripes. The microphotographs of the SEM work on the untreated achenes, which were cut in half by a razor blade, show from the outside inwards the various layers of the pericarp followed by the white testa (t) and endosperm (es) enclosing two cotyledons (cot). (Fig. 3a) [22]. From the outside to the inside, the pericarp consists of longitudinally elongated cells followed by several layers of regular cells. The last tissue of the pericarp consists of compressed parenchyma in which intercellular spaces are very obvious. The testa shows no special features. The endosperm consists of one or two layers of cells. Next are the cotyledons, which are characterized by the presence of erratic drop-like structures. The technique used to prepare the samples for the observation in the SEM does not allow for observation of the cell structures with the cotyledons. It is suggested that the cross sectioning of the achenes released oils that flowed across the surface and obscured examination. To observe the internal structure of the cotyledons, thin sections were prepared. After lipid staining with the Oil Red O solution the sections were examined by light microscopy (LM) as well as by SEM. The LM microphotographs show isodiametric cells that were coloured red and suggest that both lipids and proteins are present in one cell (not shown). Hence no separate cells containing lipids and proteins are observed. The SEM microphotographs of the thin sections show an identical structure for the cotyledons. (Fig. 3b).

After heating, the only observable external change is the colour of the achene. At $T_{\text {oven }}=280{ }^{\circ} \mathrm{C}$ portions of the achenes, which may have been white prior to exposure, are brown. At $T_{\text {oven }}=310{ }^{\circ} \mathrm{C}$ the achenes are black. No additional external changes are observed. The colour of the seeds changes from white through brown to become black at $T_{\text {oven }}=250{ }^{\circ} \mathrm{C}$. As a result of increasing heating, the achenes and the seeds shrink [23].

The internal structure of the residues of the achenes heated at $T_{\text {oven }}=310,370$ and $500{ }^{\circ} \mathrm{C}$ were examined by SEM using samples cut in half by razor blade. The SEM microphotograph of the residue heated at $310{ }^{\circ} \mathrm{C}$ show the same drop-like structures as present in the untreated achene (Fig. 3c). If free flowing oil explains the drop-like structures oil continues to be present at this temperature. In the samples heated at 370 and $500{ }^{\circ} \mathrm{C}$ the droplike structures are no longer observed. The microphotograph of the sample heated at $T_{\text {oven }}=370{ }^{\circ} \mathrm{C}$ shows many small holes in the cotyledon (Fig. 3d) and is indicative of the release of the oil at this temperature. The sample from $T_{\text {oven }}=500{ }^{\circ} \mathrm{C}$ does not show 
(a)

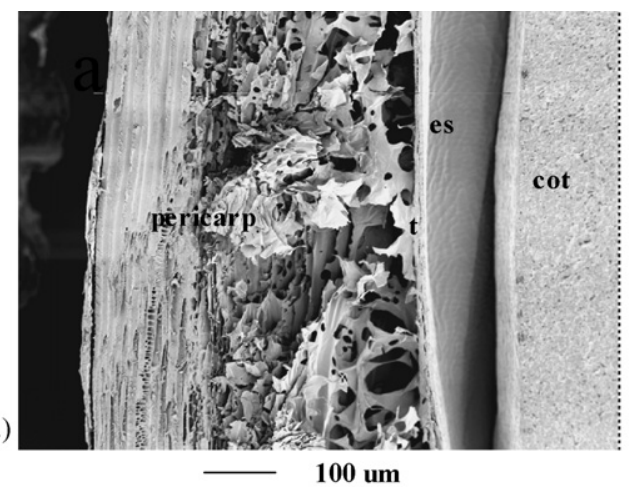

(c)

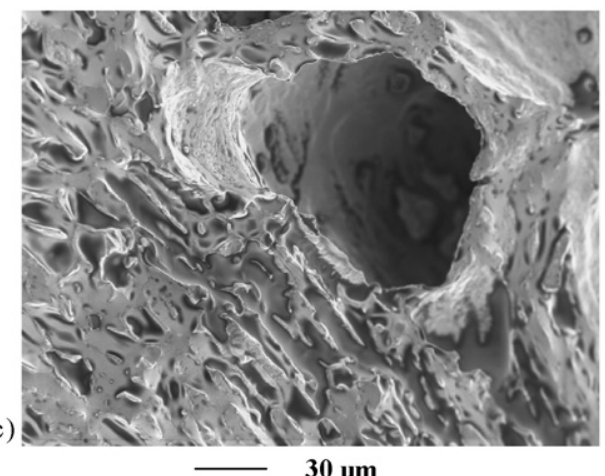

(b)

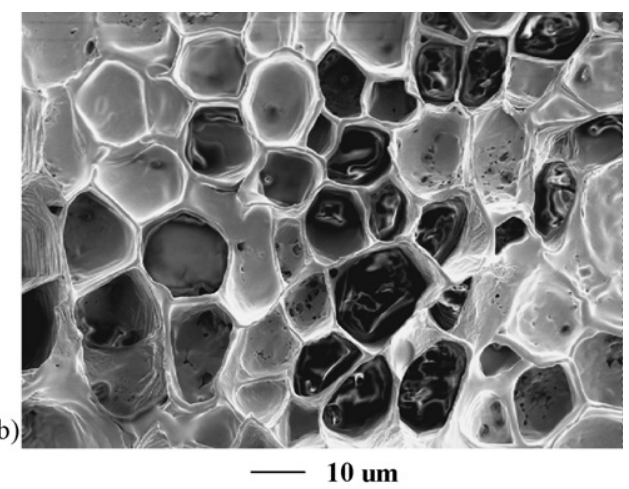

(d)

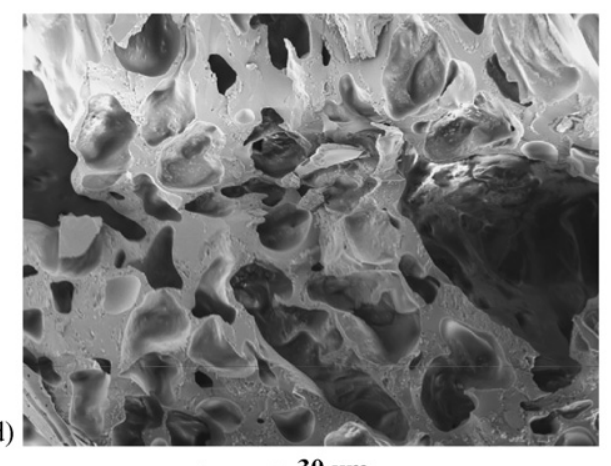

Fig. 3. SEM microphotographs of the internal structure sunflower achenes (var. Arikara). (a) untreated achene with pericarp, white testa (t), endosperm (es) and cotelydon (cot); (b) thin section of the cotelydon (a); (c) achene heated at $T_{\text {oven }}=310{ }^{\circ} \mathrm{C}$; (d) achene heated at $T_{\text {oven }}=370{ }^{\circ} \mathrm{C}$.

this feature (not shown). Despite the chemical changes the structure of the pericarp is still recognizable.

\subsection{Elemental analyses}

The elemental analyses of the untreated sunflower achenes show a C content of 54.9 wt. $\%$, daf and an $\mathrm{N}$ content of 3.68 wt.\%, daf (Fig. 4). The results of the carbon (solid squares)

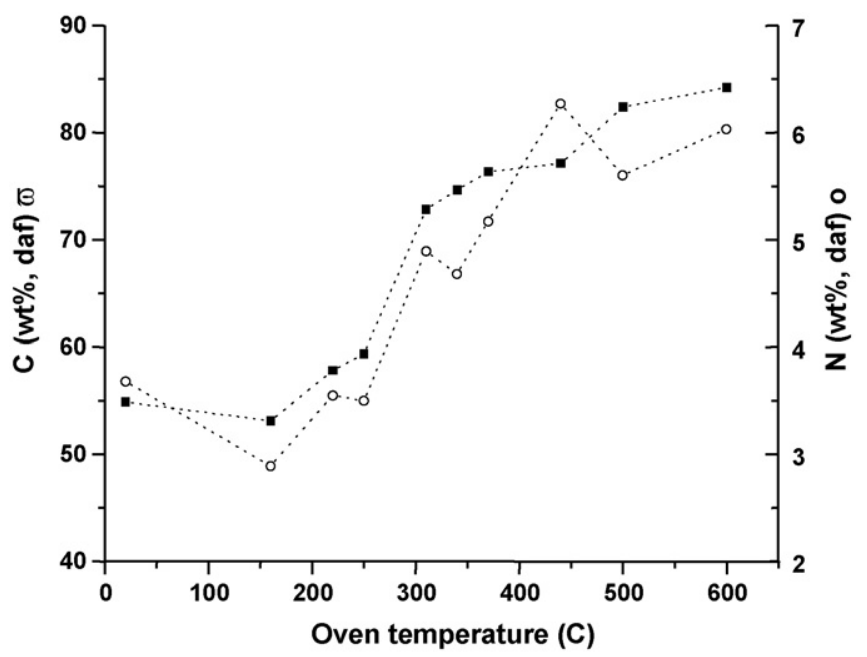

Fig. 4. The results of the bulk elemental analyses of untreated and heated sunflower achenes (var. Arikara) as a function of the oven temperature in ${ }^{\circ} \mathrm{C}$. (ם) C content in wt.\%, daf and $(\bigcirc) \mathrm{N}$ content in wt.\%, daf. Dashed lines added to aid the reader. and nitrogen (open circles) analyses of heat treated samples reveal the relative increase of the content of both elements as a function of oven temperature (Fig. 4). Starting at $T_{\text {oven }}=250{ }^{\circ} \mathrm{C}$ the $\mathrm{C}$ content increases sharply from almost $60 \mathrm{wt} . \%$ (daf) at $250{ }^{\circ} \mathrm{C}$ to $73 \%$ at $T_{\text {oven }}=310{ }^{\circ} \mathrm{C}$. Then it increases more slowly to reach almost $85 \%$ (daf) at $T_{\text {oven }}=600{ }^{\circ} \mathrm{C}$. At the same time the $\mathrm{N}$ content increases from $3.5 \mathrm{wt} . \%$ (daf) at $T_{\text {oven }}=250{ }^{\circ} \mathrm{C}$ to about $4.7 \%$ (daf) at $T_{\text {oven }}=310$ and $340{ }^{\circ} \mathrm{C}$ and further increases to $6 \%$ (daf) at $440{ }^{\circ} \mathrm{C}$. From there it remains more or less constant until $T_{\text {oven }}=600{ }^{\circ} \mathrm{C}$. The moisture content of the untreated achenes was determined as $6.1 \mathrm{wt} \%$ and the ash content as $3.2 \mathrm{wt} . \%$.

\subsection{Molecular composition by DTMS-EI}

\subsubsection{Seeds}

Lipids and proteins are the common constituents of sunflower seeds; the bulk material being lipids of which triacylglycerides constitute the major lipid class (Table 1). Polysaccharides are a relatively small component of the seed. DTMS under EI conditions has the potential to reveal important information on proteins and lipids in propagules, because the polysaccharide pyrolysis products are strongly fragmented under these conditions. In the case of sunflower seeds the polysaccharide content is rather low, which facilitates the interpretation of the results.

The total ion current (TIC) of the untreated sunflower seeds is characterized by a dominant peak in the early stage of the temperature ramp due to the evaporation of more volatile 

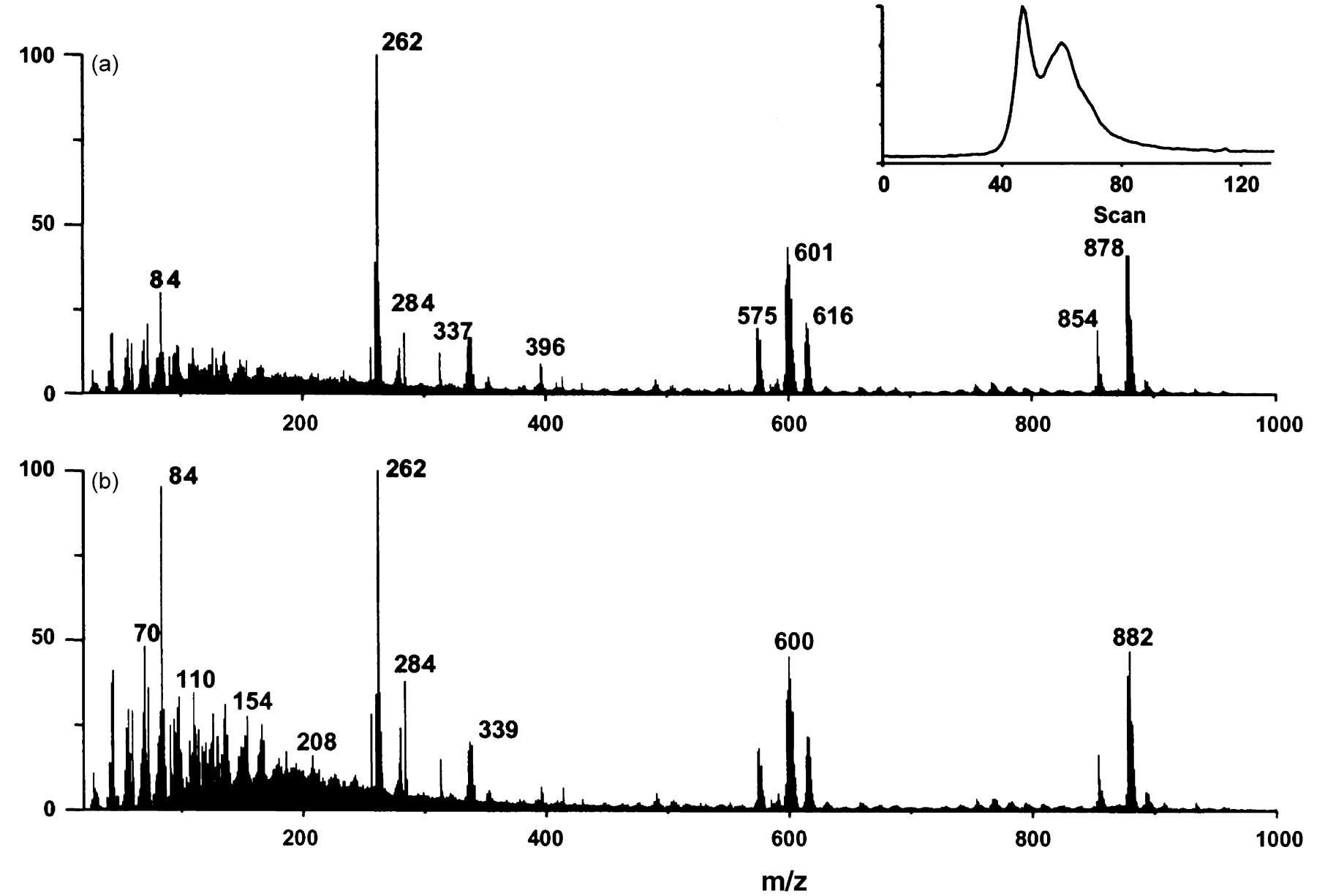

Fig. 5. DTMS-EI measurements of untreated sunflower seeds (var. Arikara). (a) Mass spectrum, inset: TIC; (b) mass spectrum (scan 55-65) showing protein markers.

components (lipids) and a lower peak at a higher temperature as a result of the dissociation of biopolymeric constituents (Fig. 5a, inset). The EI spectrum of the untreated seeds (Fig. 5a) shows the characteristics of lipids, proteins and polysaccharides. This spectrum covers both peaks of the TIC (scan 40-80), and as far as lipids are concerned the summated spectrum of the first peak (scan 40-50) is similar to the shown spectrum. The lipid fraction comprises "free" lipids such as fatty acids $(\mathrm{m} / \mathrm{z}$ $256[\mathrm{M}], \mathrm{C}_{16: 0} ; 260\left[\mathrm{M}-\mathrm{H}_{2} \mathrm{O}\right], \mathrm{C}_{18: 3} ; 262\left[\mathrm{M}-\mathrm{H}_{2} \mathrm{O}\right], \mathrm{C}_{18: 2}$; $264\left[\mathrm{M}-\mathrm{H}_{2} \mathrm{O}\right], \mathrm{C}_{18: 1} ; 280, \mathrm{C}_{18: 2}$ and $284, \mathrm{C}_{18: 0}$ ), sitosterols $\left(\mathrm{m} / \mathrm{z}, 396-414, \mathrm{C}_{29: 1}\right)$, tocopherol $(\mathrm{m} / \mathrm{z}, 430)$, diacylglycerides $\left(616, \mathrm{C}_{18: 2,18: 2}\right)$ and triacylglycerides $\left(\mathrm{m} / \mathrm{z}, 854, \mathrm{C}_{16: 0,18: 2,18: 2}\right.$; $878, \mathrm{C}_{18: 2,18: 2,18: 2} ; 880, \mathrm{C}_{18: 1,18: 2,18: 2}$ and 882, $\left.\mathrm{C}_{18: 1,18: 1,18: 2}\right)$. Characteristic for triacylglycerides is the presence of fragment ions in the mass spectra that correspond to the loss of a fatty acid carboxyl radical leaving a $[\mathrm{M}-\mathrm{RCOO}]^{+}$from the molecular ion, as can be observed at $m / z 575\left(\mathrm{C}_{18: 1}\right), 599\left(\mathrm{C}_{18: 1}\right.$ and $\left.\mathrm{C}_{18: 2}\right)$, $601\left(\mathrm{C}_{18: 1}\right.$ and $\left.\mathrm{C}_{18: 2}\right)$ and $603\left(\mathrm{C}_{18: 2}\right)$. Ions that correspond to $74 \mathrm{amu}$ added to the acylium ion, i.e., $[\mathrm{RCO}+74]^{+}$leaving monoacylglyceryl fragments are observed at $\mathrm{m} / \mathrm{z} 313\left(\mathrm{C}_{16: 0}\right)$, $337\left(\mathrm{C}_{18: 2}\right), 339\left(\mathrm{C}_{18: 1}\right)$ and $341\left(\mathrm{C}_{18: 0}\right)$. All these masses are in accordance with the type of lipids found in sunflower seeds (Table 1)

Low voltage EI protein markers are usually found in the range of $m / z, 130-220[7,8]$. Typical ions in this range and the lower mass range are present in the spectrum of Fig. 5a, but are more prominent in the summated spectrum from the high temperature side (between scans 55 and 65) of the TIC trace (Fig. 5b). Visible are $m / z 69$ (Val, Leu, Lys, Gln); 70, 154, 194 (Pro, Arg, Lys); 84 (Glu, Val, Lys); 91 (Phe); 94, 107, 108, 136 (Tyr); 110 (His); 117 (Trp); 138 (Leu, Hpro); 152, 166, 180 (Leu) and 186 (Tyr) $[7,8]$. These amino acids are also present in the proteins of sunflower seeds [15].

The small polysaccharide fraction is represented by mass peaks $m / z$ 43, 57, 60, 73, 98 and 126 (Fig. 5b), derived from hexosesugars $[7,8]$. Pentosesugars representing hemicelluloses are usually represented by anhydroxyloses with markers $m / z, 85$ and 114 , but are not observed as major peaks in the spectra of the sample of the seeds.

The TIC's of the sampled residues heated at $T_{\text {oven }}=160$ $250{ }^{\circ} \mathrm{C}$ are similar to that of the untreated seed (Fig. 5a). They are still characterized by the presence of the dominant peak at the early stage of the temperature ramp and are followed by a smaller peak. The apex remains for both peaks at the same temperature, indicating no change in the bulk molecular composition of the material. At $T_{\text {oven }}=310{ }^{\circ} \mathrm{C}$ the TIC trace still shows two peaks, but the apex of the second peak has moved to a higher temperature, a first indication of the formation of a thermally more stable material (not shown). In the TIC trace of the sample heated at $340{ }^{\circ} \mathrm{C}$ three peaks are 


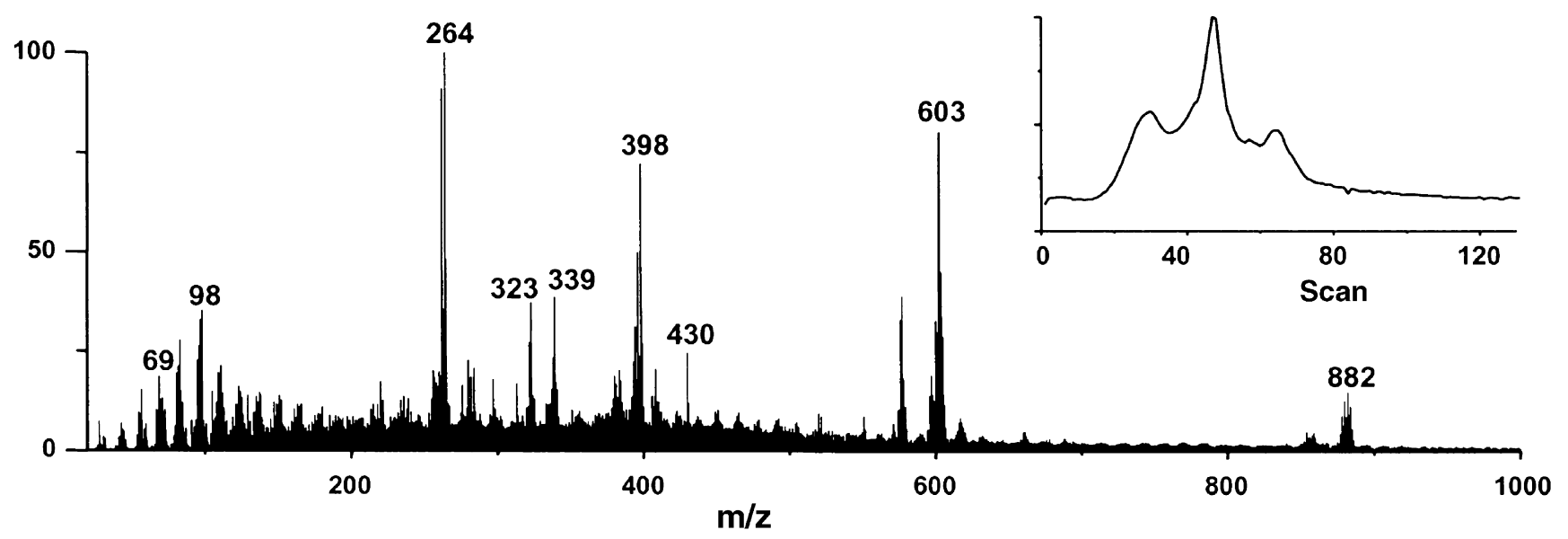

Fig. 6. DTMS-EI mass spectrum of samples of sunflower seeds (var. Arikara) heated at $T_{\text {oven }}=340{ }^{\circ} \mathrm{C}$, inset: $\mathrm{TIC}$.

observed (Fig. 6, inset). The apex of the two peaks at the higher temperatures is in the same position as in the previous sample. The first and new peak at the lower end of the temperature range represents probably a number of new lipid markers, resulting from the heating process. At $T_{\text {oven }}=370{ }^{\circ} \mathrm{C}$ the TIC shows only one peak with a sharp product distribution with temperature, which has shifted to a higher temperature, pointing to the presence of an increased amount of condensed thermally more stable material (not shown). At $T_{\text {oven }}=440{ }^{\circ} \mathrm{C}$ the trace has a defined broader distribution. From $T_{\text {oven }}=500{ }^{\circ} \mathrm{C}$ the $\mathrm{TIC}$ becomes very irregular indicative of instrumental noise due to very low amounts of detectable compounds.

The mass spectra of the samples of sunflower seeds heated from $160{ }^{\circ} \mathrm{C}$ upwards show mass peaks that describe the conversion of a lipid and protein rich material as a function of the temperature. The DTMS of the sample heated at $250{ }^{\circ} \mathrm{C}$ is still characterized by the presence of lipids and proteins. In the spectra of the samples heated at $T_{\text {oven }}=310$ and $340{ }^{\circ} \mathrm{C}$ (Fig. 6), the main peaks are those representing lipids or their fragments, while protein derived markers have a low relative intensity. The latter are aliphatic compounds $(\mathrm{m} / \mathrm{z}, 57,69,83$ and 97) and alkylbenzenes $(\mathrm{m} / \mathrm{z} 91,105$ and 119$)$. The mass peaks derived from lipids show a shift from unsaturated to more saturated moieties. Examples are the shift from $\mathrm{m} / \mathrm{z} 878$ as the highest peak of the triacylglycerides to $m / z 882$ and the related fragments ions $m / z 603,577$ and 339. The fatty acid with the highest relative intensity is now $\mathrm{C}_{18: 1}(\mathrm{~m} / \mathrm{z} 264)$ instead of $\mathrm{C}_{18: 2}$ $(\mathrm{m} / \mathrm{z}$ 262). Strikingly the mass peaks representing sitosterol $\mathrm{C}_{29: 1}\left(\mathrm{~m} / \mathrm{z} 396, \mathrm{M}-\mathrm{H}_{2} \mathrm{O}\right)$ and tocopherol $(\mathrm{m} / \mathrm{z} 430, \mathrm{M})$ have at this temperature a high relative intensity and apparently a high resistance against thermal degradation than the other lipid moieties. Moreover, three characteristic mass peaks appear in this spectrum, e.g., $\mathrm{m} / \mathrm{z}$ 98, 322/323 and 398. The presence of $\mathrm{m} /$ $z 98$ has been explained as a fragment ion (heptene) of the side chain of steroids [24]. The presence of $m / z 398$ is probably related to a reduction process of the $\mathrm{C}_{29}$ steroids leading to a $\mathrm{C}_{29}$-sterane. The significance of the ions at $\mathrm{m} / \mathrm{z} 323$ and 322 is presently unknown. Between 340 and $370{ }^{\circ} \mathrm{C}$ the triacylglycerides apparently have evaporated as most of the lipid markers and their fragment ions are not observed anymore in the spectrum of $T_{\text {oven }}=370{ }^{\circ} \mathrm{C}$, but the ions $\mathrm{m} / \mathrm{z}, 264$ and 284 are still recognized (Fig. 7). The fragment ion from sterols $\mathrm{m} / \mathrm{z} 98$ still has a high relative intensity. The spectrum of the sample heated at the latter temperature shows two series of aliphatic moieties $m / z$ 42, 56, 70, etc. (alkenes) and 43, 57, 71, etc. (alkanes). The aromatic compounds in the spectrum are

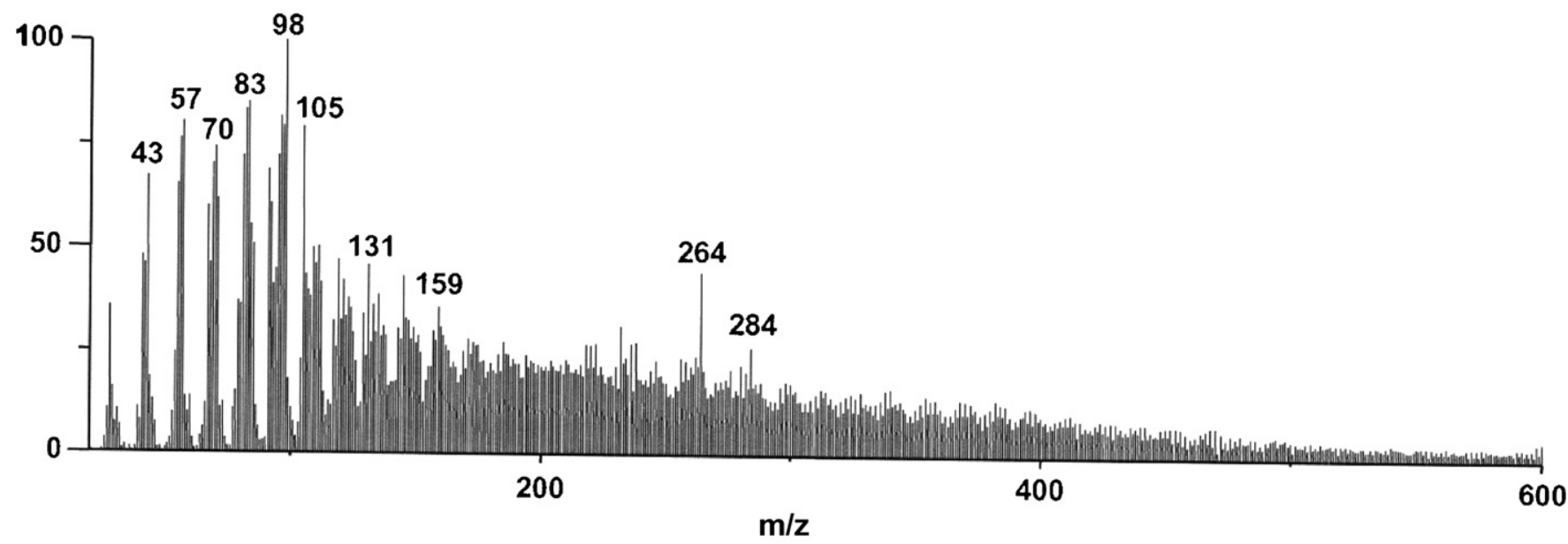

Fig. 7. DTMS-EI mass spectrum of samples of sunflower seeds (var. Arikara) heated at $T_{\text {oven }}=370{ }^{\circ} \mathrm{C}$. 
represented by the alkylbenzenes $\mathrm{m} / \mathrm{z}, 91,105$ and 119 , and a series of odd numbered masses $\mathrm{m} / \mathrm{z} 117,131,145$ and 159, (alkyl)indoles derived from protein. It shows the beginning of the conversion of the original biomaterial, except the lipids, into an aromatic condensed material. In the spectrum of the sample heated at $440{ }^{\circ} \mathrm{C}$ no lipid markers are observed (not shown). The same aliphatic and aromatic moieties are still recognized. New moieties in this spectrum are elimination products from $\mathrm{N}$ containing polyaromatics like $m / z, 27(\mathrm{HCN})$ and $41\left(\mathrm{CH}_{3} \mathrm{CN}\right)$ and $\mathrm{m} / \mathrm{z} 28(\mathrm{CO})$ and $44\left(\mathrm{CO}_{2}\right)$ from $\mathrm{O}$-containing polyaromatic compounds. Also $\mathrm{m} / \mathrm{z} 78$ (benzene) is present and masses representing condensed aromatic compounds such as $m / z, 146$, 160, 182, 196 and 208. Finally, from about $500{ }^{\circ} \mathrm{C}$, a strongly $\mathrm{C}$-enriched material has developed characterized by mass peaks $m / z, 27,28,41,44,78$ and 91 pointing to the release of $\mathrm{HCN}$, $\mathrm{CO}, \mathrm{CO}_{2}$, benzene and alkylbenzene from the aromatized residue.

\subsubsection{Achenes}

Sunflower achenes are the seeds enclosed by a pericarp or hull. Accordingly the main constituents are the lipids and proteins present in the seeds and to which are added the constituents of the pericarp, i.e., polysaccharides and lignin (Table 1). The presence of these different biopolymers result in a more complex pyrolyzate. Each polymer system generates its own chemical moieties with a characteristic mass distribution and appearance temperature.

The TIC of the sample of the untreated achene shows two peaks, as in the sample of the seed, but the peak at the lower end of the temperature range is rather low and the second peak is the predominant (Fig. 8, inset).

The EI spectrum of the untreated sample has an ion distribution that represents the characteristic mass peaks of lipids, proteins, polysaccharides and lignin (Fig. 8). Ions representing the lipid and protein fraction are identical to those present in the spectrum of untreated seeds (Fig. 5a); however, the relative intensity of the protein markers, such as $m / z, 70$ and 84, is much lower. Mass peaks $m / z$ 43, 57, 60, 73, 98, 126 and 144 are derived from hexosesugars (cellulose) and $\mathrm{m} / \mathrm{z} 85$ and 114 from pentosesugars (hemicelluloses) [7,8]. The main lignin markers in this spectrum are the monomeric guaiacyl units $\mathrm{m} / \mathrm{z}$ $124,137,138,150,151,164,178,180$ (partly) and the syringyl units $m / z$ 154, 167, 194, 208, 210 [25]. The major mass peaks are assigned to coniferyl alcohol $(\mathrm{m} / \mathrm{z}, 180)$ and sinapyl alcohol $(\mathrm{m} / \mathrm{z} 210)$. In the higher mass region, dimeric lignin markers are visible, e.g., $m / z$ 272, 328, 340, 388 and 418.

The TIC traces of the samples heated from $T_{\text {oven }}=160$ up to $250{ }^{\circ} \mathrm{C}$ have a similar configuration as the trace of the untreated achenes with the apex of the largest peak at 70 scans. The apex of the largest peak shifts to 80 scans in the TIC trace of the sample heated at $T_{\text {oven }}=280{ }^{\circ} \mathrm{C}$ to remain constant up to $T_{\text {oven }}=340{ }^{\circ} \mathrm{C}$, indicative of the presence of a thermally more stable material. The TIC traces of the residues heated at $T_{\text {oven }}=370{ }^{\circ} \mathrm{C}$ and higher show only one peak at 85 scans and the trace starts to broaden on the high temperature side. The TIC traces of the samples from $T_{\text {oven }}=500{ }^{\circ} \mathrm{C}$ and higher are very irregular.

The samples heated at $T_{\text {oven }}=160,220$ and $250{ }^{\circ} \mathrm{C}$ have an identical mass distribution as the sample of the untreated achene (Fig. 8). It is noted that from $T_{\text {oven }}=220{ }^{\circ} \mathrm{C}$ the relative intensity of the lipid markers increases. The spectrum of the sample heated at $T_{\text {oven }}=280{ }^{\circ} \mathrm{C}$ (not shown) points to the first changes in the distribution of the individual masses compared to the previous spectra. The characteristic lipid, protein, polysaccharide and lignin markers are still present, but new mass peaks $(\mathrm{m} / \mathrm{z} 110,124$ and 138, representing (alkyl)dihydroxybenzenes), which are related to the thermally degraded lignin, are also observed. At $T_{\text {oven }}=340{ }^{\circ} \mathrm{C}$ the typical mass peak patterns for proteins and polysaccharides are no longer observed (Fig. 9). The mass spectrum shows clusters of three mass peaks with $\left(\mathrm{CH}_{2}\right)$ mass increments such as $m / z, 146,147$, $148 ; 160,161,162$, etc. that correspond to a homologues series of condensed aromatic compounds and mass peaks related to alkylated phenols and benzenes such as $m / z$ 91, 92, 94, 105, 107, 108 and 122. These mass peaks are typical products resulting from the thermal degradation of polysaccharides [7,8]. A series of odd numbered masses $(\mathrm{m} / \mathrm{z}, 117,131,145,159$, etc.) are identified as (alkyl)indoles derived from proteins $[7,8]$. The lipid fraction is still recognized by the presence of $\mathrm{m} / \mathrm{z} 256$, $262,264,280,602$ and 880, indicating a shift from unsaturated

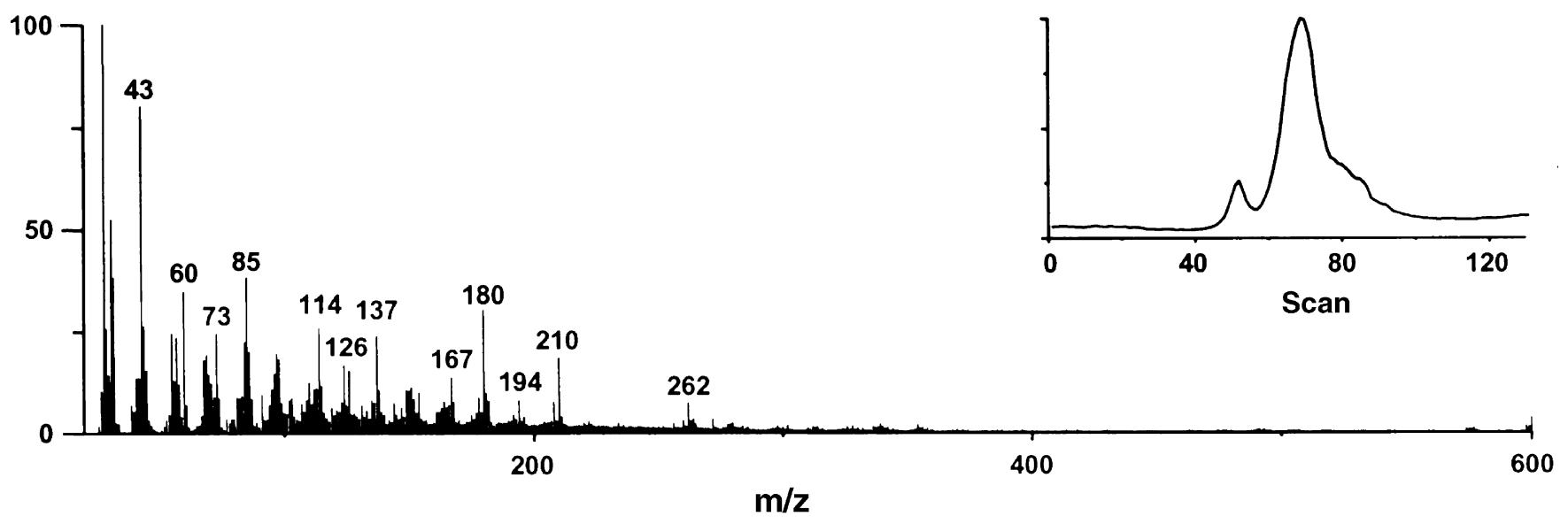

Fig. 8. DTMS-EI mass spectrum of samples of untreated sunflower achenes (var. Arikara), inset: TIC. 


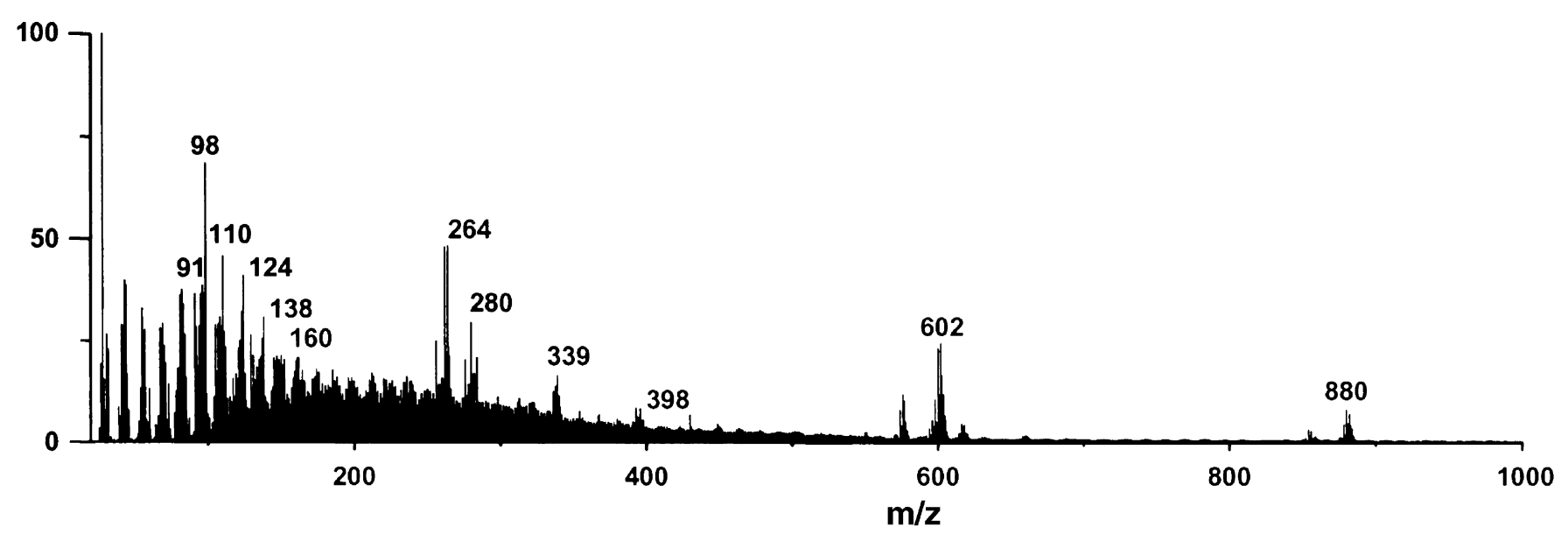

Fig. 9. DTMS-EI mass spectrum of samples of sunflower achenes (var. Arikara) heated at $T_{\text {oven }}=340{ }^{\circ} \mathrm{C}$.

to more saturated moieties. New mass peaks such as $\mathrm{m} / \mathrm{z} 98$, $322 / 323$ and 398 , as already described in the previous section about seeds, are also present. In the spectrum of the sample heated at $T_{\text {oven }}=370{ }^{\circ} \mathrm{C}$ the relative intensity of mass peaks $\mathrm{m} / \mathrm{z}$ $110,124,138$ is considerably decreased. Now the main peaks are series of alkanes, alkenes, (alkyl)phenols, (alkyl)benzenes and condensed aromatic compounds (not shown). The lipid fraction has a different behaviour and at $370{ }^{\circ} \mathrm{C}$ its characteristic markers are not observed. Evidently, it evaporates at a temperature higher than $340{ }^{\circ} \mathrm{C}$. But evaporation is not the only degradation process for the lipids as indicated by the presence of the new mass peaks.

Lastly, at temperatures higher than $440{ }^{\circ} \mathrm{C}$, the material changes into a strongly $\mathrm{C}$-enriched material that is characterized by a very low amount of pyrolyzed products (not shown). The spectra show ions that represent elimination products from

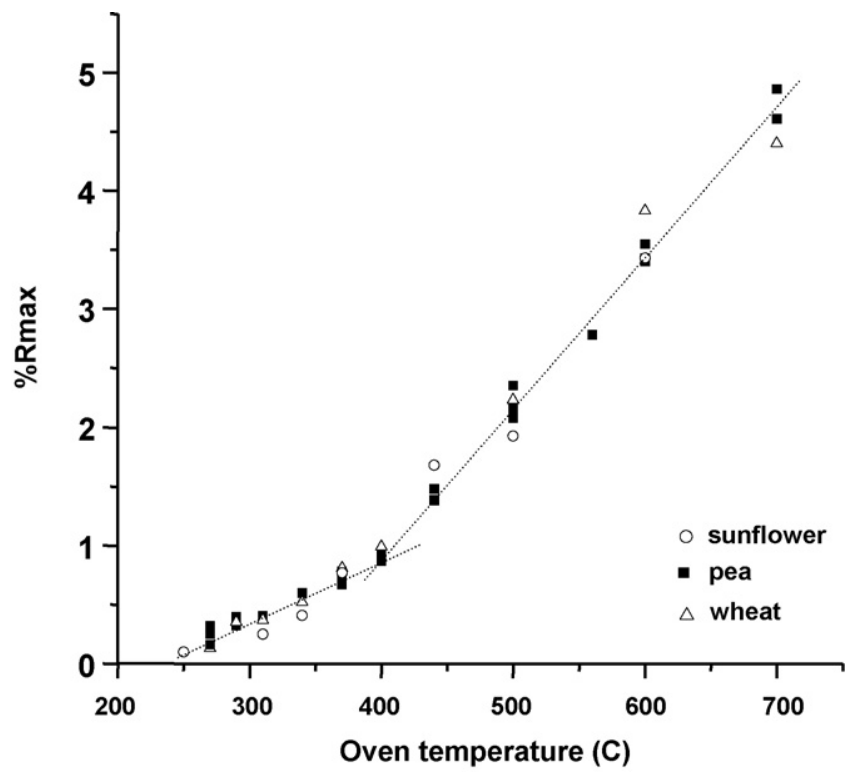

Fig. 10. The results of the reflectance $\left(\% R_{\max }\right)$ measurements of heated sunflower achenes (var. Arikara), pea seeds and wheat grains as a function of the oven temperature in ${ }^{\circ} \mathrm{C}$. ( $\left.\bigcirc\right)$ Sunflower achene, $(\square)$ pea seeds and $(\triangle)$ wheat grains. Dashed lines added to aid the reader.
$\mathrm{N}$-containing polyaromatic compounds like $\mathrm{m} / \mathrm{z}, 27(\mathrm{HCN})$ and $41\left(\mathrm{CH}_{3} \mathrm{CN}\right)$ and $m / z 28(\mathrm{CO})$ and $44\left(\mathrm{CO}_{2}\right)$ from O-containing polyaromatics. Also $\mathrm{m} / \mathrm{z}, 78$ (benzene) is present indicative of the highly condensed material. From $T_{\text {oven }}=280{ }^{\circ} \mathrm{C}$ to the sample heated at $440{ }^{\circ} \mathrm{C}$ the protein, lignin and polysaccharide fractions of the material gradually change into an aromaticrich, highly condensed material $[7,8]$, while lipids evaporate or disappear by other means.

\subsection{Reflectance measurements}

Vitrinite is one of the three main categories of microscopically recognizable organic compounds of coal that are, in analogy to minerals, collectively called macerals [19]. As a result of a gradually changing molecular structure (aromatization) the vitrinite reflectance increases with coal rank. Although sunflower achenes do not contain vitrinite, a reflectance can be measured on polished samples as soon as enough aromatic moieties are present. From $T_{\text {oven }}=270{ }^{\circ} \mathrm{C}$ upwards the formation of aromatic moieties increases and on the samples heated at $270{ }^{\circ} \mathrm{C}$ and higher a reflectance can be measured. The reflectance of the lowest temperature samples rises slowly from $T_{\text {oven }}=270$ up to $400{ }^{\circ} \mathrm{C}$ (open circles in Fig. 10). Thereafter the reflectance rises more rapidly. The S.D. of the measurements increases from 0.059 at $T_{\text {oven }}=310$ to 0.21 at $600{ }^{\circ} \mathrm{C}$. For comparison the reflectances measured on samples of pea seeds and wheat grains, heated under the same experimental conditions, are incorporated in Fig. 10. The results show that for each temperature the measured reflectances are almost identical for all the propagules.

\section{Discussion}

This study is part of a project to determine the physical and chemical properties of carbonized plant material before it would have been deposited into sediments and thus become part of the archaeological record. To obtain further insights into the carbonization process of whole plant parts a simulation in the laboratory was performed by heating, under the experimental conditions as described in this paper, of modern counterparts of 
propagules found in the archaeological record. The following species were selected: pea seeds, wheat grains and sunflower achenes and seeds. The main constituents of pea seeds and wheat grains are polysaccharides (starch), proteins and a rather small lipid fraction $(<2 \mathrm{wt} . \%)$. The physical and chemical properties versus temperature, as a result of heating, of these propagules as well as the two major constituent biopolymers have been studied extensively. For the results of polysaccharides see Pastorova et al. [26] and Boon et al. [27], for proteins and whole propagules see Braadbaart et al. [6-8] and the references cited therein. The main conclusion of these studies is that the untreated polysaccharide and protein rich material of the propagules gradually converses, as a function of temperature, into a material that consists of aromatic moieties at $T_{\text {oven }}=310^{\circ} \mathrm{C}$. At higher temperatures the same mass distribution is observed for both propagules. From this temperature up to $440{ }^{\circ} \mathrm{C}$ a disproportionation occurs by loss of $\mathrm{CO}$ and $\mathrm{CO}_{2}$ leading to a further condensation of the aromatic structure. Above $440{ }^{\circ} \mathrm{C}$ the DTMS-EI spectra are characterized by very low amounts of detectable material. The main ions released are phenols $(\mathrm{m} / \mathrm{z}$ 94), (alkyl)benzenes $(\mathrm{m} / \mathrm{z}$ 78, 91 and 92) and the N-containing compounds $\mathrm{HCN}(\mathrm{m} / z$ 27) and $\mathrm{CH}_{3} \mathrm{CN}(\mathrm{m} / \mathrm{z} 41)$. The elemental analyses show both a strong $\mathrm{C}$-enrichment as well as an increasing $\mathrm{N}$-content, versus temperature (Fig. 4).

The present study focuses on the effects of heat treatment on the third species of the project: sunflower achenes and seeds. The achenes consist of a seed enclosed by the pericarp or hull. The main constituents of a seed are lipids and proteins. The achene is the seed enclosed by the pericarp and its chemical structure can be described as a ligno-cellulosic. Hence the four main biopolymers that are met in plant material are present in sunflower achenes, namely lipids, proteins, polysaccharides and lignin. The conversion of both polysaccharides as well as proteins has been the subject of the abovementioned studies, and it is possible to use the results for the present study. The main biopolymers in seeds are lipids and proteins (Table 1), which show their characteristic markers in the DTMS-EI spectra of the untreated seeds. As a result of heating the protein fraction converses into a $\mathrm{N}$-containing aromatic material $[7,8]$. This is confirmed by the elemental analyses, showing a relative $\mathrm{N}$-content of $3.68 \mathrm{wt} \%$ (daf) for the untreated seeds and a gradual increasing to $6.03 \mathrm{wt} . \%$ (daf) for the residues heated at $600{ }^{\circ} \mathrm{C}$. The lipids show a different behaviour. In the samples heated up to $T_{\text {oven }}=340{ }^{\circ} \mathrm{C}$ the lipid markers, as present in the untreated sample, are still observed. The sample heated at $T_{\text {oven }}=370{ }^{\circ} \mathrm{C}$ does not show these markers anymore suggesting that the lipids are not present anymore as a result of the heating. At $T_{\text {oven }}=310$ and $340{ }^{\circ} \mathrm{C}$ mass peaks $m / z, 98,322 / 323$ and 398 are observed with a high relative intensity. It is suggested that $\mathrm{m} / \mathrm{z}, 98$ and 398 are derived from sterol. The results show a trend whereby with increasing heating temperature unsaturated moieties are replaced by more saturated moieties and $m / z, 398$ is tentatively attributed to this process. Sitosterol and tocopherol show a high resistance against thermal degradation, which complies with the results of a study by Britt et al. [28] indicating that steroids convert into various condensed aromatic moieties at high temperatures. We believe that evaporation of lipids is not the only process, but that lipids are also thermally converted into other moieties.

The SEM study on the untreated achenes shows that no separate cells are present in the seed for lipids and proteins and hence each cell contains lipids as well as proteins. As the bulk of the lipids are still present up to $340{ }^{\circ} \mathrm{C}$ it means that the mass loss of the achenes up to this temperature will be less compared to pea seeds and wheat grains, which contain hardly any lipids. This explains the smaller mass loss up to $340{ }^{\circ} \mathrm{C}$ of sunflower achenes and seeds compared to the latter two propagules (Fig. 2).

The DTMS-EI spectra of the untreated achenes show the characteristic markers for proteins, polysaccharides and lignin under the present experimental conditions. The conversion, as a result of heating, of proteins and polysaccharides has been examined before as mentioned above [7,8,26,27]. The fourth polymer present in sunflower achenes is lignin. Lignin is a complex, heterogeneous and three-dimensional polymer. It is formed in the case of sunflowers from trans-coniferyl and trans-sinapyl alcohol, which differ only by the number of methoxy groups on the aromatic ring [24,28]. Lignin has many different types of linkages between the monomer units. Pyrolysis will therefore result in several competing thermal degradation reactions, during which different bonds will dissociate at different temperatures, depending on the bond energies. The mass spectrum of the untreated achenes shows a high abundance of the monomers guaiacyl and syringyl alcohols (Fig. 8) characteristic for hardwood lignin. The spectra of the samples heated at 310 and $340{ }^{\circ} \mathrm{C}$ show a high abundance of the mass peaks $\mathrm{m} / \mathrm{z} \quad 110,124$ and 138 . Demethylation and demethoxylation of guaiacyl and syringyl derivatives will result in the formation of dihydroxybenzene $(\mathrm{m} /$ $z$ 110), a product that is observed frequently in the various suggested schemes showing the major products as a result of heat treatment of lignin [25]. The mass peaks $m / z, 124$ and 138 can be attributed alkyldihydroxybenzenes or methoxyphenols. These main peaks $(\mathrm{m} / \mathrm{z}, 110,124$ and 138) are present in the spectra of the samples of sunflower achenes heated at 310, 340 (Fig. 9) and $370{ }^{\circ} \mathrm{C}$, but at higher temperatures these masses are not present anymore. From $T_{\text {oven }}=440{ }^{\circ} \mathrm{C}$ upwards very low amounts of detectable of compounds are observed and only mass peaks related to phenols $(\mathrm{m} / \mathrm{z}, 94,107,108)$ and benzenes $(\mathrm{m} / \mathrm{z}, 78,91,92,105)$ are visible. So also lignin thermally converses via various aromatic compounds into a strongly $\mathrm{C}$ enriched material, which cannot be distinguished by DTMS-EI from polysaccharide and protein derived material.

Reflectance measurements on polished surfaces of samples of achenes confirm these results. The presence of aromatic compounds and more specific the condensed aromatic compounds and graphitic carbon structures are the basis for the measurement of reflectances. The aromatic sheets that may occur singly or in groups of two or more are stacked parallel to one another. This molecular structure becomes more ordered as the heating temperature is increased. The increased ordering is accompanied by a pronounced increase of aromatics and a corresponding loss of aliphatic material. Solid-state ${ }^{13} \mathrm{C} N M R$ 
measurements on pea seeds heated show that from $T_{\text {oven }}=500{ }^{\circ} \mathrm{C}$ the aliphatic material is not present anymore, while at $600{ }^{\circ} \mathrm{C}$ still a strong signal for aromatic material is present [29]. These changes in molecular structure and the ordering of the aromatic sheets with increasing temperature explain the gradual increase of the reflectance (Fig. 10). As the reflectance at each temperature is identical for both the lignin containing sunflower achenes as well as for pea seeds and wheat grains, it demonstrates that the molecular structure of the aromatic compound itself determines the reflectance. The increasing degree of condensation of the aromatic compounds is accompanied by an increasing reflectance.

\section{Conclusions}

This study focuses on the change, as a function of the temperature, of the physical and chemical properties of sunflower achenes and seeds. For this purpose the specimens are heated for $60 \mathrm{~min}$ under anoxic conditions. It is part of a project that has already investigated these changes in pea seeds and wheat grains, both polysaccharide/protein rich propagules. The results of the latter studies show that from temperatures higher than $310{ }^{\circ} \mathrm{C}$ the chemical properties of both biopolymers are identical. Hence from a chemical point of view both materials cannot be distinguished. The morphology of both polysaccharide/protein rich propagules remains intact, during the heating process, and this makes it possible to identify these propagules.

Apart from these two biopolymers, sunflower achenes contain lipids and lignin. By heating the pericarp separately the thermal conversion of lignin has been studied by DTMS-EI. In the spectra of these samples mass peaks $\mathrm{m} / \mathrm{z} 110,124$ and 138 are observed, which are not present in the pyrolysis products of polysaccharide/protein rich material heated at the same temperatures under identical experimental conditions. We suggest that at $T_{\text {oven }}=310$ and $340{ }^{\circ} \mathrm{C}$ the conversion of lignin follows its own unique pathway. Hence in this range of temperatures there is a difference between propagules containing lignin and propagules that consist solely of the other two biopolymers. At higher temperatures this difference is not present anymore and the spectra and thus the chemical composition of the heated samples of the three polymers have become identical.

Lipids show a totally different behaviour, compared to polysaccharides, protein and lignin, when heated under the present experimental conditions. The DTMS-EI measurements show the characteristic markers for lipids in the spectrum of the untreated sample and this does not change in the spectra of the samples heated at $T_{\text {oven }}=160-340{ }^{\circ} \mathrm{C}$. The markers are no longer observed in the spectrum of the sample heated at $T_{\text {oven }}=370{ }^{\circ} \mathrm{C}$. It can be concluded that between 340 and $370{ }^{\circ} \mathrm{C}$ the lipids have dissociated and evaporated. This absence explains the lesser mass loss of sunflower achenes and seeds compared to pea seeds and wheat grains. However, evaporation does not seem to be the only process, from $T_{\text {oven }}=310^{\circ} \mathrm{C}$ new mass peaks are observed in the spectra of the DTMS-EI measurements but they again disappear at $T_{\text {oven }}=370{ }^{\circ} \mathrm{C}$. We suggest that the chemical composition from a small fraction of the lipids changes at temperatures between 310 and $370{ }^{\circ} \mathrm{C}$. Based on the chemical properties it can be concluded that the lignin containing propagules (e.g., sunflower achenes) can be distinguished from non-lignin containing propagules (peas and wheat grains) to a temperature of $340-370{ }^{\circ} \mathrm{C}$. At higher temperatures the chemical properties of the investigated species are identical. The reflectance measured on the polished surfaces of the investigated propagules confirms this conclusion.

\section{Acknowledgements}

Technical assistance with the study of the internal morphology and scanning electron microscopy by Dr. W. de Priester (Clusius Laboratory, Leiden University, The Netherlands) is gratefully acknowledged. We thank Ms K. Reimer (Geochemical Research, TNO-NITG, The Netherlands) for her assistance with the vitrinite reflectance measurements. This research is supported by FOM research program 49 funded by the Foundation for Fundamental Research on Matter (FOM), a subsidiary of the Dutch Organisation for Scientific Research (NWO).

\section{References}

[1] W. van Zeist, Palaeohistoria 14 (1970) 41.

[2] V.M. Bryant Jr., in: C.C. Mathewson (Ed.), Interdisciplinary Workshop on the Physical-Chemical-Botanical Processes Affecting Archaeological Sites, U.S. Army Corps of Engineers, Washington, DC, 1989.

[3] M.B. Schiffer, Am. Antiquity 48 (4) (1983) 675.

[4] M.B. Schiffer, Formation Processes of the Archaeological Record, Albuquerque University of New Mexico, 1987 Chapter 8.

[5] C.C. Bakels, Analecta Praehistorica Leidensia 17 (1984) 1.

[6] F. Braadbaart, J.J. Boon, H. Veld, P. David, P.F. van Bergen, J. Archaeol. Sci. 31 (2004) 821.

[7] F. Braadbaart, J.J. Boon, J. van der Horst, P.F. van Bergen, J. Anal. Appl. Pyrol. 71 (2004) 997.

[8] F. Braadbaart, J. van der Horst, J.J. Boon, P.F. van Bergen, J. Therm. Anal. Calorim. 77 (2004) 957.

[9] D. Zohary, M. Hopf, The Domestication of Plants in the Old World, Oxford University Press, Oxford, 2001.

[10] A.J. Brewer, in: M.C.R. McCullough, C.J. Faulknor (Eds.), Excavations of the Higgs and Doughty Site, I-75 Salvage Archaeology, Tennessee Archaeological Society, Knoxville Tennesee, 1973.

[11] G. Fritz, in: K.J. Gremillion (Ed.), People, Plants and Landscapes: Studies in Paleoethnobotany, University of Alabama Press, Tuscaloosa, 1997.

[12] C.B. Heiser, The Archaeological Record of Cultivated Sunflower with Remarks Concerning the Origin of Indian Agriculture in Eastern North America, Manuscript on File, Anthropology Department, University of Missouri, St. Louis, 1953.

[13] C.B. Heiser, personal communication.

[14] S. González Pérez, Physico-Chemical and Functional Properties of Sunflower Proteins, University of Wageningen, Wageningen, 2003.

[15] Nuria Canibe, Mercedes Martin Pedrosa, Luz M ${ }^{a}$ Robredo, Knud Erik Bach Knudsen, J. Sci. Food Agric. 79 (1999) 1775.

[16] Narpinder Singh, Randhir Singh, Kulwander Kaur, Harmit Singh, Food Chem. 66 (1999) 241.

[17] D.K. Salunkhe, J.K. Chavan, R.N. Adsule, S.S. Kadam, World Oilseeds: Chemistry Technology and Utilization, Van Nostrand Reinhold, New York, 1992.

[18] J.A. Robertson, Crit. Rev. Food Sci. Nutr. 6 (1975) 201.

[19] H. Veld, Organic Petrology of the Westphalian of the Netherlands, University of Utrecht, Utrecht, 1995. 
[20] International Standard, Methods for the petrographic analysis of bituminous coal and anthracite. Part 2. Method of preparing coal samples, Ref. no. ISO 7404/2-1985(E).

[21] International Standard. Methods for the petrographic analysis of bituminous coal and anthracite. Part 5. Method of determining microscopically the reflectance of vitrinite, Ref. no. ISO 7404-5, 1994 (E).

[22] J.G. Vaughan, The Structure and Utilization of Oil Seeds, Chapman and Hall Ltd., London, 1970.

[23] F. Braadbaart, P.J. Wright. submitted to Economic Botany, under revision.
[24] P.F. Britt, A.C. Buchanan III, M.J. Cooney, D.R. Maretineau, J. Org. Chem. 65 (2000) 1376.

[25] E.R.E. van der Hage, M.M. Mulder, J.J. Boon, J. Anal. Appl. Pyrol. 25 (1993) 149.

[26] I. Pastorova, R.E. Botto, P.A. Arisz, J.J. Boon, Carbohyd. Res. 262 (1994) 27.

[27] J.J. Boon, I. Pastorova, R.E. Botto, P.W. Arisz, Biomass Bioenergy 7 (1-6) (1994) 25.

[28] P.F. Britt, A.C. Buchanan III, M.K. Kidder, C.V. Owens Jr., J. Anal. Appl. Pyrol. 66 (2003) 71.

[29] F. Braadbaart, unpublished results. 